\title{
Polygyny as an Adaptive Alternative to Monogamy in Two Species of Dippers: Cinclus Mexicanus and Cinclus pallasii*
}

\author{
Donna Hansen**
}

\section{Introduction}

While relatively little is known of their breeding biology, the Cinclidae, or dippers, are presently considered monogamous by most authors. However, there are sufficient observations of behavior suggesting polygyny and sufficient characteristics of the species and their environments to allow them to adopt a polygynous mating system.

The purpose of this study was to investigate the breeding season behavior of the Japanese species, $C$. pallasii, and the American species, $C$. mexicanus in order to determine the mating system of these two species and possible reasons for the presence of that mating system. A study of C. mexicanus was conducted during the spring of 1977 in the Sierra Nevada foothills of California, and C. pallasii was studied in Hakone National Park, Japan, during the spring of 1978. Observations were concentrated on the following behavior patterns: territoriality, pair-formation, nest construction, courtship display, mate switching, mating, incubation and care of young, and behavior of young.

There is very little information on the reproductive behavior of the avian family, Cinclidae. The most recent studies on Cinclus mexicanus have treated nesting behavior (Hann 1950), life history, territoriality, and population studies (Bakus 1959a, 1959b), and polygyny (Price and Bock 1973). Studies of C. pallasii and C. cinclus were recently conducted by Sunquist (1974) and Hewson (1967), respectively.

The following descriptions of the general life history of dippers refer to both $C$. mexicanus and $C$. pallasii unless otherwise stated. (For further information, see Burgham 1904, Cordier 1927, Ehinger 1930, Robson 1956, and Goodge 1959).

The American dipper, Cinclus mexicanus, is a stumpy, brownish-grey bird occurring in clear, cool rushing streams from Alaska and British Columbia throughout the Rocky Mountains and Cascade-Sierra Ranges south to Mexico and Central America. They generally occur at elevations of 600 to $3000 \mathrm{~m}$.

The Japanese dipper, Cinclus pallasii, is very similar in appearance to C. mexicanus, but is about $30 \%$ larger (Tables 1 and 2, Fig. 1), and is a chocolate brown color. $C$. pallasii displays a sexual dimorphism in body size, not seen in C. mexicanus, with the male being about $8 \%$ larger than the female (Table 2 and Fig. 2). They occur in rushing streams throughout the mountains of Japan at elevations as low as $600 \mathrm{~m}$. They also occur throughout the mountains of Asia.

Dippers seldom leave the course of the stream on which they live, though Skinner

* A thesis submitted in partial fulfillment of the requirements for the degree of Master of Arts in the Department of Biology California State University, Fresno.

** 3901 W San Juan Dr. Tucson, Arizona 85713, U.S.A. 
Table 1. Individuals studied, date banded, band numbers and colors, and bird's measurements at the time of banding. (Cinclus mexicanus)

\begin{tabular}{cccccccccc}
\hline \hline Territory & $\begin{array}{c}\text { Date } \\
\text { banded }\end{array}$ & $\begin{array}{c}\text { Band } \\
\text { No. }\end{array}$ & $\begin{array}{c}\text { I.D. No. from } \\
\text { color bands }\end{array}$ & Sex & \multicolumn{3}{c}{ Measurements (mm) } & \multicolumn{2}{c}{ Weight } \\
Culmen & Wing & Tail & (gm) \\
\hline 3 & $3-3-77$ & 25 & 0121 & $?$ & 16.9 & 82.9 & 43.8 & 51.5 \\
3 & $3-3-77$ & 30 & 0144 & $?$ & 15.6 & 89.9 & 47.8 & 55.5 \\
1 & $3-5-77$ & 41 & 0155 & M & 17.0 & 89.6 & 47.9 & 54.5 \\
1 & $3-20-77$ & 41 & 0155 & M & 17.0 & 89.6 & 47.9 & 50.5 \\
1 & $3-5-77$ & 42 & 0166 & F & 17.3 & 85.6 & 43.6 & 55.5 \\
1 & $3-20-77$ & 46 & 0131 & F & 16.1 & 80.0 & 43.0 & 51.5 \\
\hline \multicolumn{7}{l}{ Averages of measurements } \\
\hline
\end{tabular}

Table 2. Individuals studied, date banded, band numbers and colors, and bird's measurements at the time of banding. (Cinclus pallasii)

\begin{tabular}{|c|c|c|c|c|c|c|c|c|}
\hline \multirow{2}{*}{ Territory } & \multirow{2}{*}{$\begin{array}{c}\text { Date } \\
\text { banded }\end{array}$} & \multirow[t]{2}{*}{ Band No. } & \multirow{2}{*}{$\begin{array}{l}\text { I.D. No. from } \\
\text { color bands }\end{array}$} & \multirow[t]{2}{*}{ Sex } & \multicolumn{3}{|c|}{ Measurements (mm) } & \multirow{2}{*}{$\begin{array}{l}\text { Weight } \\
\text { (gm) }\end{array}$} \\
\hline & & & & & Culmen & Wing & Tail & \\
\hline Ryokan & $3-6-78$ & $050-09751$ & 0111 & $\mathrm{~F}$ & 20 & 88 & 64 & 75 \\
\hline Ryokan & $3-6-78$ & 050-09752 & 0555 & M & 21 & 102 & 69 & 78 \\
\hline Ryokan & $12-27-77^{*}$ & $050-05005$ & 0044 & F & 20 & 96 & 61 & 70 \\
\hline Miyagino & $3-6-78$ & $050-09753$ & 0000 & $\mathrm{~F}$ & 19 & 91 & 63 & 70 \\
\hline Miyagino & $3-6-78$ & $050-09754$ & 0333 & M & 20 & 105 & 71 & 86 \\
\hline Miyagino & $3-31-78$ & 050-09755 & 0551 & $?^{* *}$ & 15 & 83 & 51 & 55 \\
\hline \multicolumn{3}{|c|}{ Average of measurements } & & & 20 & 96 & 66 & 76 \\
\hline
\end{tabular}

* Banded by Abe,

** Fledgling from Miyagino territory-measurements not included in averages

(1922) saw one fly overland a quarter mile between streams. Their territories are usually confined to within the banks of the river and they rarely land in a tree or on the bank, perching instead on rocks in the stream. They are disturbed by an excessive presence of man, and may leave the area completely (Steiger 1940).

Dippers fly like quail with short, even wing beats. They dip up and down almost constantly while perched on rocks except while preening or resting. The dipping motion is like a series of quick curtsies; the legs are bent and straightened so that the entire body moves up and down, the wings and tail are flicked downward.

Dippers obtain food, including aquatic insects, larvae, small fish, and some aquatic flora, from the stream. They often feed in shallow areas, usually facing into the current with head and shoulders under water. When they catch a small fish, they beat it against a rock, then often eat it whole. Dippers also feed in the deeper pools, where they swim much like a duck, then dive, using their wings to propel themselves under water. They are able to walk on the bottom of the pool while feeding (Ingram et al. 1938, Brownlow 1949).

The nest of the dipper appears to be a ball of moss and is usually attached to the face of a large rock or cliff, often behind or beside a waterfall. The nest is frequently completely concealed inside a pipe located in the face of a man-made dam (as was the 


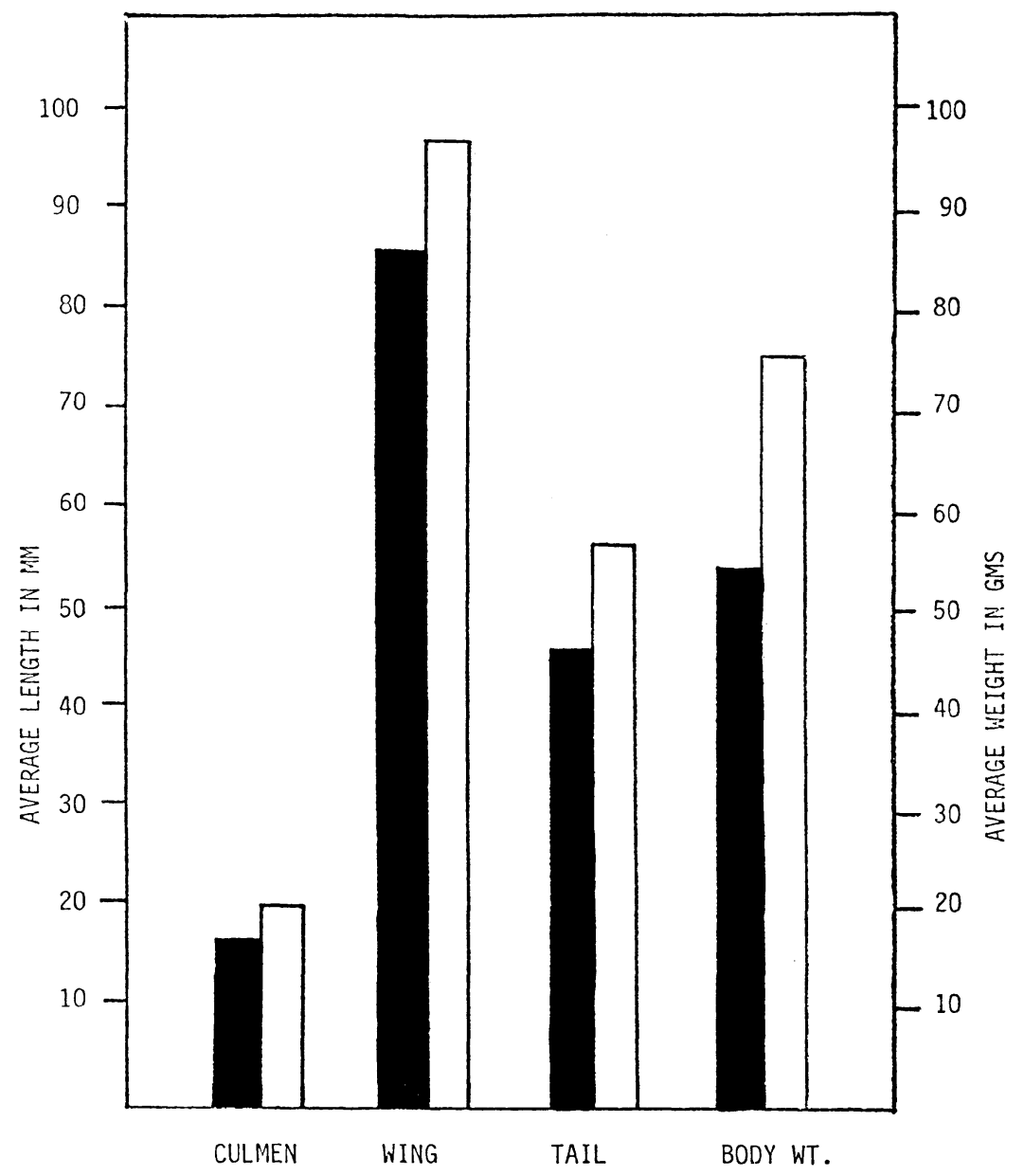

Fig. 1. Size difference between $C$. mexicanus ( $\mathbf{a}$ ) and $C$. pallasii $(\square)$ by measurements of culmen, wing, tail, and body weight.

case of three nests in this study) or built under a bridge, or on other man-made structures. The lining of the nest consists of dry leaves and grass. The male has been reported to help build the outside of the nest (Henderson 1908, Rankin and Rankin 1940), but usually does not help with the lining. Often an old nest will be reused (Bakus 1959a, Hann 1950) so that only the lining need be replaced, since the lining is removed soon after the young fledge (Hann 1950). In instances where an old nest is used, the male probably does not help with nest construction.

The female usually lays one egg a day and begins incubation shortly after the last one has been laid. She lays three to five eggs which take about 16 days to hatch (Hann 1950).

Dippers are altricial, and for the first week to 10 days after hatching the female 


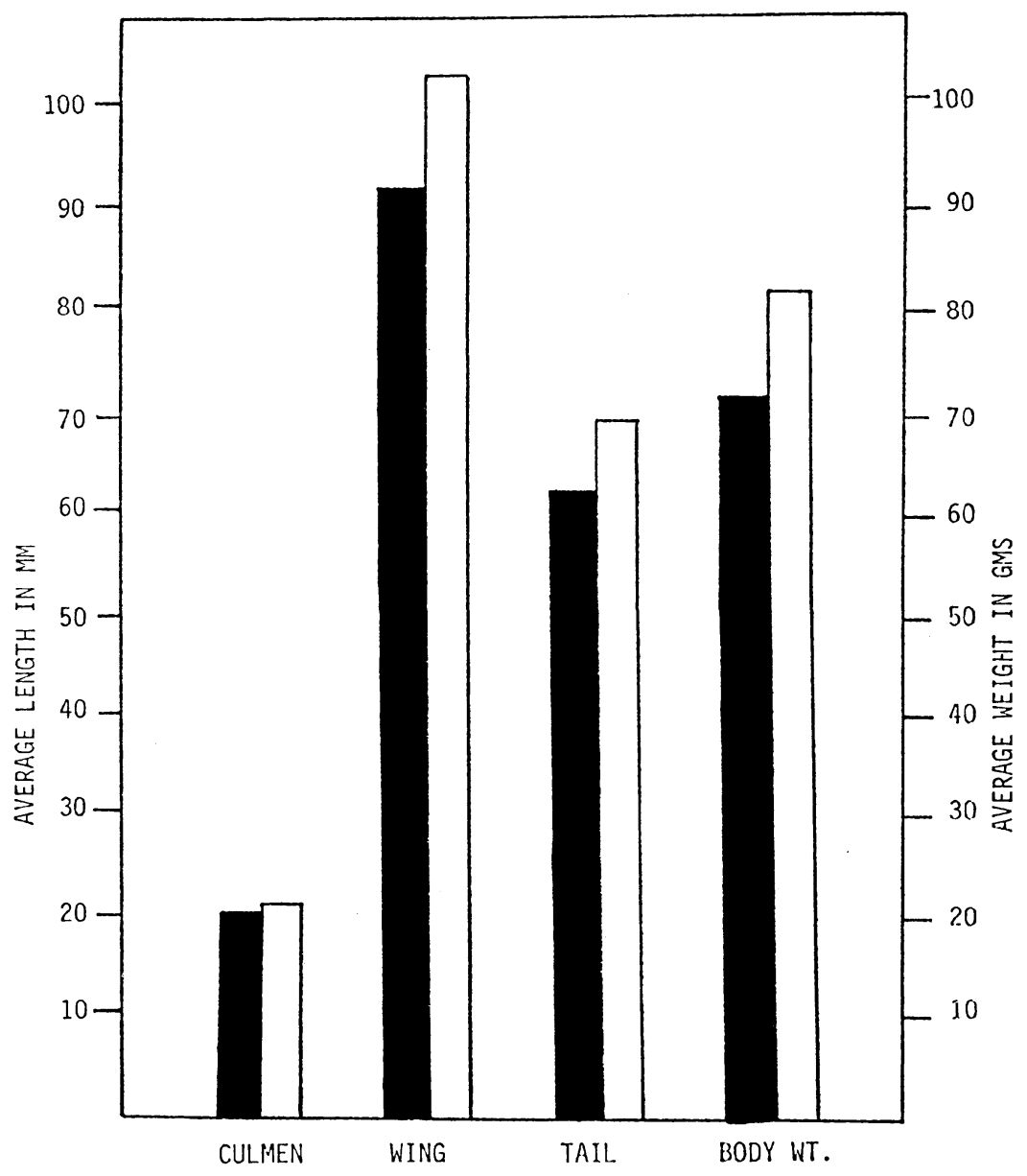

Fig. 2. Size difference between female ( $\square$ ) and male ( $\square$ ) C. pallasii by measurements of culmen, wing, tail, and body weight.

continues to brood her young (Hann 1950). As with other altricial birds, the young are not yet homeothermic. Early growth involves a rapid increase in muscle, liver, and heart tissues, which allows for an increase in rate of metabolism and ability to maintain homeostasis. Later development of feathers allows for better temperature regulation (Whittow 1970). The period of poikilothermy in dipper nestlings is not yet known but would appear to be 7 to 10 days (Hann 1950).

The young generally spend 20 to 30 days in the nest before fledging (Hann 1950). Once they leave, they cannot return to the nest as they are not yet adept enough to maneuver themselves through a waterfall, or other swift-flowing water, to the nest.

Since the breeding biology of these two species is best described in the context of the environments in which they live, each study area and the behavior observed in it is described separately peior to discussion. The discussion attempts to combine the 
observations from the two studies, and information available from previous studies of dippers for each stage of reproductive behavior-territoriality, courtship displays, mate switching, nest construction, incubation, care of young, and fledgling behavior-before examining the strategies of a polygynous mating system, and how the dipper is able to utilize polygyny as an adaptive alternative to monogamy.

\section{Reproductive Behavior of Cinclus Mexicanus}

\section{Study area and methods}

The study area was located on Big Creek (Township 11 South, Range 25 East) in eastern Fresno County, California, and extended from a bridge at an elevation of $500 \mathrm{~m}$ downstream to the outlet of Big Creek into Pine Flat Lake, elevation approximately $250 \mathrm{~m}$ (Fig. 1). The stream averaged about $6 \mathrm{~m}$ wide, varying from 2 to $20 \mathrm{~m}$. Depth at a gaging station (Fig. 1) ranged from $0.5 \mathrm{~m}$ to $0.7 \mathrm{~m}$. Stretches of shallow water flowing rapidly over and around large boulders were interspersed with deep quiet pools.

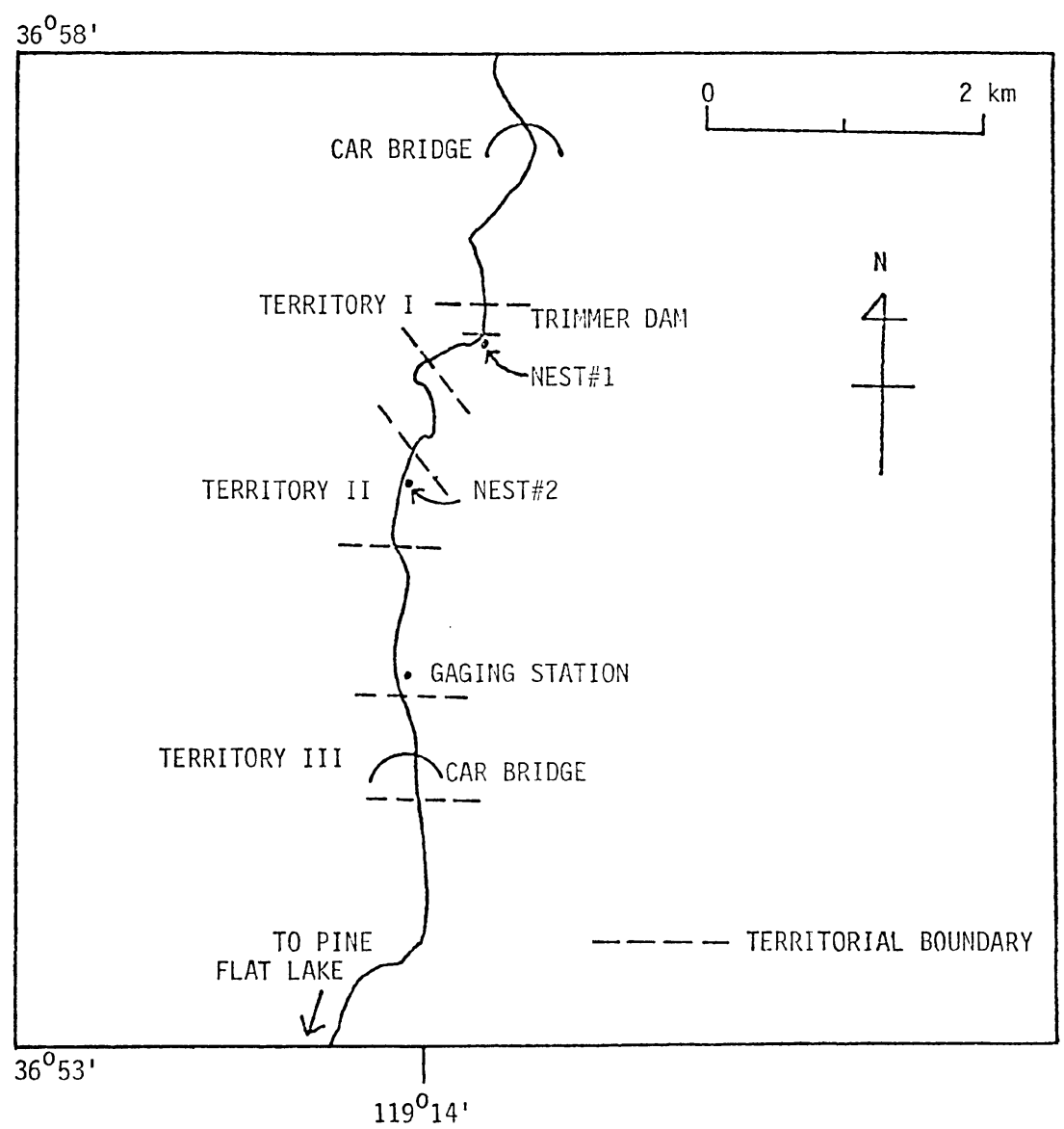

Fig. 3. Study area on Big Creek, Fresno County, Sierra Nevadas, California, in 1977. 
Cottonwood (Populus fremontii), alder (Alnus rhombifola), and willow (Salix sp.) were the dominant macrovegetation along the stream edge.

The study occurred during the second year of a drought that altered greatly the dipper habitat. Most streams leading into Big Creek became dry early in March, reducing the number of available nesting sites.

Most observations were made near the nest of a pair of dippers at a small manmade dam that crossed Big Creek about $8.5 \mathrm{~km}$ above Pine Flat Lake at an elevation of $400 \mathrm{~m}$ (Fig. 3). The overflow from the dam formed a small waterfall, then cascaded down a large granite rock into a deep, wide pool before continuing as a narrow stream. Above the dam was a large, calm pool. The dam was about $2 \mathrm{~m}$ high, with two $25 \mathrm{~cm}$ diameter metal pipes located two-thirds of the way down and extending $8 \mathrm{~cm}$ out from the face of the dam. Nest $\# 1$ was located in one of these pipes, the pipe forming the roof of the nest. When the water level was high enough for water to flow over the dam, it cascaded over the dam, obscuring the pipe opening. On top of the dam were short stone pillars on which the dippers often perched.

Nest $\# 2$ was located about $2 \mathrm{~km}$ downstream from nest $\$ 1$ in the middle of a $3 \mathrm{~m}$ wide portion of the stream on the side of a large boulder about $2 \mathrm{~m}$ high. Beside the nest was a $2 \mathrm{~m}$ high natural waterfall that sprayed the nest continuously and even obscured the nest from view when the water level was high. Below the nest was a small pool with several large rocks. Past the pool the stream narrowed for $0.5 \mathrm{~km}$, then became wider with $6 \mathrm{~m}$ high boulder forming walls on either side.

Territory III was located about $3 \mathrm{~km}$ farther downstream from Territory II, beginning just below the gaging station and running about $1.5 \mathrm{~km}$, to just beyond a car bridge. The birds in this territory were observed for a short time in February and March. After mid-March, campers and fishermen frequented the area to such a degree that the dippers did not stay to build a nest.

From 1 February through the end of May 1977, I made observations for 2 to 5 hours 2 days each week either in the early morning or late afternoon. First, territorial boundaries were distinguished. As I followed the birds up or down the stream their flights became shorter as they neared the boundary of their territory; once the territorial border was reached, the birds turned back and flew past me rather than crossing into another bird's territory. Once I determined where the boundaries were located, mist nets were set within each territory so that the bottom of the net was in the water. Rocks were placed on the bottom rung to avoid space between the water and net, since the dippers usually flew just above the water. The birds were chased into the nets. Nets were reset only if unmarked dippers moved in and remained in the territories. Each individual was weighed, measured, and marked with Fish and Wildlife Service Size 1-A aluminum band and a plastic color band placed on the left leg, and two color bands on the right leg (Table 1). Six colors were used and each had a designated number: $0=$ aluminum, $1=$ red, $2=$ orange, $3=$ yellow, $4=$ green, $5=$ blue, $6=$ purple. $A$ marked individual was referenced by reading the bands up the left leg, then down the right. Originally the birds were given a four-digit number, for example 0155 . In this paper, the 0 is dropped and the appropriate letter ( $\mathrm{M}$ for male and $\mathrm{F}$ for female) is inserted. 
I observed the dippers with $7 \times 50$ binoculars and recorded data in a notebook. I concentrated on observing territorial, mating and nesting behavior.

\section{Observations}

\section{Territoriality}

The American dipper is very territorial, especially from November through June or July, and will not allow another dipper to enter its territory, except during the mating and nesting seasons. In this study, when an intruder crossed into a guarded territory, it was chased out with the territorial defense flight. This flight was usually high over the water, rather than the usual flight very close to the water, and was accompanied by a loud, continuous chattering call. This call was also heard when the birds were disturbed and often helped locate a bird that had been nearby and in front of me.

If the territory contained a pair of dippers, chases were executed by both. One case was observed in which the banded male tolerated an unbanded newcomer in his territory until his banded mate appeared and initiated the chase, at which time the male joined in the chase.

Territories included about $1 \mathrm{~km}$ of stream length, and extended the full width of the stream. The dippers spent most of their time in the middle to upper reaches of their territory and the nest was usually located there. Often, a large rock in the stream served as the major lookout point, and the bird perched there a great deal of time, singing, preening, or resting.

\section{Pair Formation}

Pair bond formation occurred early in the breeding season for C. mexicanus, and preceded courtship displays and nest building (Fig. 4). This sequence of events varies

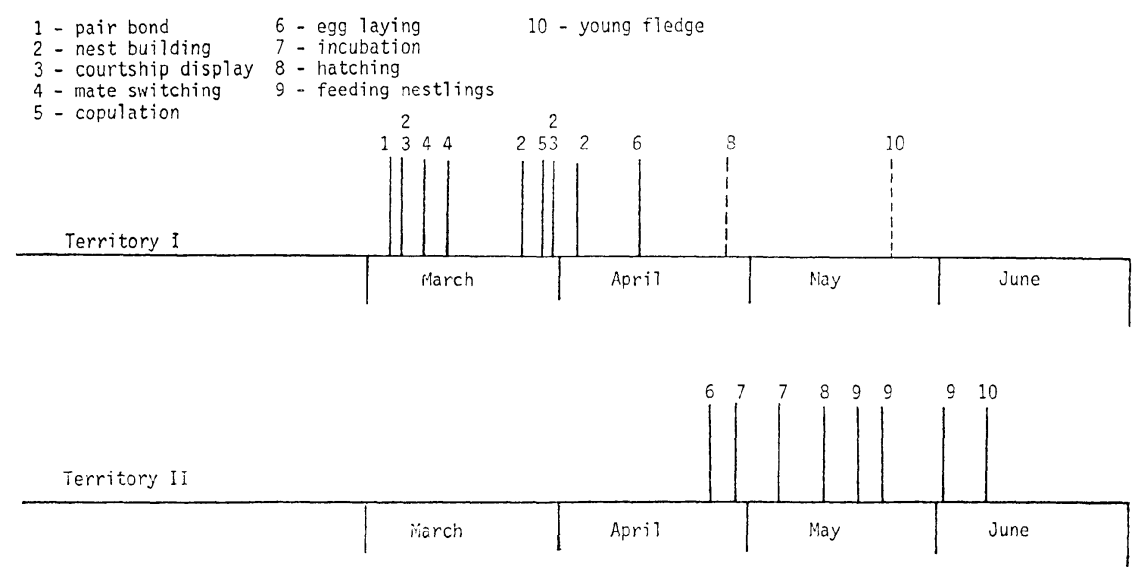

Fig. 4. Occurrence of phases of reproductive behavior in $C$. mexicanus from March through June, 1977 in two adjoining territories on Big Creek, California. Note moderate asynchrony in female reproductive cycles, allowing for greatest amount of male help to occur staggered (between hatching, 8, and fledging, 10) should polygyny exist. Broken line indicates calculated dates for behavior to occur, when they were not observed. 
from the usual order of courtship before pair formation (Wallace and Mahan 1975). I considered individuals paired when a male tolerated the female in his territory. The pair flew close together, low over the river, without continuous calling of the territorial defense flight and rested near each other. The earliest indication of pair formation in the spring of 1977 occurred on 9 February in Territory III (Fig. 1). A nest was never seen in this territory and the pair was not seen after 27 March, probably because of the drastic drop in water level and the number of people frequenting the area.

Another pair was first observed on 3 March in Territory I (Fig. 4). Most observations reported in this paper are on members of this territory. Pair formation was not observed in Territory II since only the female was present throughout the study.

\section{Nest Construction}

Shortly after pair formation occurred between the male, M155, and the female, F166, of Territory I, the female began to collect nesting material, and carry it to the nest, located in the pipe in the dam. This was first observed on 10 March 1977. The male was never seen carrying nesting material into the nest, but did pick up nesting material and fly around with it. The female picked up and carried mainly dry leaves and pine needles to the nest, indicating she was lining an existing nest.

On 24 March, M155 and his new mate, F311 (see mate switching section), were observed at nest building as follows; M155 and F311 flew close together all morning. F311 flew into the pipe with nesting material; M155 followed, but without nesting material, Two minutes later, F311 flew out of the pipe, followed by M155 a minute later. In about 5 minutes more, both birds returned to the pipe after a trip downstream. F311 flew in with more nesting material, but M155 did not enter the pipe. When F311 came out of the pipe, M155 flew to her and attempted to mate. Again F311 flew in with nesting material, and when she came out, M155 again tried to mate. Then M155 flew into the pipe alone without nesting material, staying about 2 minutes. F311 fed near the nest for awhile, while M155 picked up nesting material and dropped it back where it was. F311 pulled at some long grass along the stream edge. When F311 flew downstream to collect more nesting material, M155 stayed near the nest, dipping and singing. F311 carried material to the nest nine times in 1 hour, staying in the pipe from $1 / 2$ to $2 \frac{1}{4}$ minutes at each visit. M155 usually went into the pipe after F311 left, remaining about 1 minute. By noon, the pair had stopped nest construction and retired downstream.

Courtship Display

The most commonly seen display was what I called the vertical stretch display, performed by either one member or by both simultaneously. The dipper strutted up to its mate with its wings lowered slightly and held away from the body, head up, and breast out, so that the bird appeared to be stretched vertically. The display was usually accompanied by continuous singing. Copulation was never seen to directly follow this display: instead one of the pair would start feeding or fly away, or both birds would remain perched near each other for awhile longer.

The stretch display was first observed on 10 March in two separate situations. The first time occurred when M155 flew to F166, his mate at the time, on the dam just above their nest. During the display, which lasted 15 seconds, F166 merely stood 
beside him. This display was observed a second time on 10 March after the pair had chased an intruder from the territory. F166 returned to the dam about 1 minute before M155. As soon as he returned F166 flew over to him on the dam and both birds displayed.

Another courtship display observed is what I referred to as the circular display flight, which appears to be very similar to the territorial defense flight. Two (or three) dippers flew very high over the water while circling the nest area. This flight differs from the territorial defense flight, which also occurred high, in that the dippers circled the nest area instead of flying along the course of the river. The flight was accompanied by continuous calling by one or more of the participants.

\section{Mate Switching}

Nest building and courtship displays indicated that F166 and M155 had formed a pair bond by 3 March. Ten days later, however, an unbanded dipper was tolerated by M155 in the vicinity of the nest. When F166 appeared she chased the intruder and was joined by M155 (see territoriality section). After the chase, both birds performed the vertical stretch display (described in courtship display section).

On 17 March, an unbanded dipper and M155 fed and stayed close together, indicating a pair bond had been formed. The unbanded dipper performed the vertical stretch display to M155 and both flew into the nest pipe. Each time one of them flew downstream, the other followed. F166 was observed downstream in M155's territory, but not in the area of the nest. Near her was an unbanded dipper which I assumed was the same one seen with M155, as they had both flown downstream previous to this sighting, but there was no territorial defense by either F166 or the unbanded dipper toward each other.

On 20 March, mist nest were set just below the vicinity of the nest. M155 and two unbanded dippers of undetermined sex were captured, but F166 was not seen.

On 24 March, F311 was identified as M155's new mate. Only these two birds were seen in the territory. F311 took over building the nest where F166 had ended.

\section{Mating}

On 27 March, three dippers, M155, F166, and F311, were in the nest area. At first, the two females tolerated each other, but shortly there-after, they began chasing each other and seemed to take turns being dominant, as one, then the other, initiated chases around the territory.

All three birds spent more time than previously on the rock face to the far side of the pool, as if expanding their territory for accomodation of the other bird. Vertical stretch displays and circular flight displays were performed by all three birds at some time during the day, as described below. Once, while the two females were on the rock face, M155 flew to them and F166 displayed to him. M155 then copulated with F166 on the rocks, the male straddling the female's back, both birds fluttering their wings. F311 now acted much more aggressively than before toward F166 and spent a great deal of time chasing her and singing. Even when chased, F166 stayed in the nest area, flying to a height of about $15 \mathrm{~m}$, circling over the road beside the stream and the trees on the side of the pool rather than up or down the stream as was usually the case when 
chased. F166 was once observed to perch in a tree, which is very unusual for a dipper.

At another time when both females were present, M155 mated, without prior display, this time with F311 in the water. F311 was completely under water during copulation, M155 straddling her body and fluttering his wings. At this point, F166 became the aggressive female.

The females fought twice, flying at and grasping one another by their beaks. Breast to breast, with feet digging into each other, they tumbled over the rocks and down the falls. The second time, F166 flew down to F311 while she was feeding and pecked at her back. Once again, they held each other with their beaks, until they broke apart and chased each other around the territory. While the females fought, M155 seemed undisturbed by what they were doing and fed a good distance away from them.

After approximately 2 hours of agonistic behavior that included fighting and chasing, F311 chased F166 from the territory and she was not seen in it again.

Two days later, on 9 March, F311 had resumed nest building in Territory I. By 12 April, about 2 weeks after copulation, the finished nest contained four eggs.

On 3 April, F166 was seen about $0.5 \mathrm{~km}$ downstream. Later that day, when we next sighted her, M155 was about $100 \mathrm{~m}$ upstream from her. During the next 2 weeks, we searched that stretch of river several times looking for the nest of F166, but found neither nest nor her.

Incubation

On 24 April, I found another nest about $2 \mathrm{~km}$ downstream in Territory II. It was built on the downstream face of a rock next to a small waterfall and contained one egg. There was an unbanded dipper in the nest area. By 28 April, there were four eggs in the nest and the unbanded dipper was incubating the eggs. The female raised the young alone, as she was the only adult dipper in the territory throughout incubation and feeding of the young.

The female spent an average of 62 minutes incubating the eggs, and 16 minutes outside the nest feeding (Table 3). The exception to this pattern was 12 May, the day of hatching, when she spent about 1 hour and 20 minutes in the nest and 10 minutes outside. Had the male been present during incubation, a different pattern may have occurred since the male feeds the incubating female (Hann 1950).

Table 3. Time spent on and off the nest by female C. mexicanus during incubation.

\begin{tabular}{|c|c|c|c|c|}
\hline Investigator & Date & Time of day & $\begin{array}{l}\text { Time on } \\
\text { (min.) }\end{array}$ & $\begin{array}{c}\text { Time off } \\
\text { (min.) }\end{array}$ \\
\hline \multirow[t]{6}{*}{ Hansen } & $4-28-77$ & $\mathrm{AM}$ & 47 & 12 \\
\hline & & & 59 & 17 \\
\hline & $5-5-77$ & $\mathrm{AM}$ & & 17 \\
\hline & & & 51 & 15 \\
\hline & $5-12-77^{*}$ & $\mathrm{AM}$ & 80 & 22 \\
\hline & & & 74 & 10 \\
\hline Average & & & 62 & 16 \\
\hline Hann & 1950 & & 80 & $12-21$ \\
\hline Goodge & 1959 & & $32-34$ & $7-10$ \\
\hline
\end{tabular}

* one egg hatching 
Table 4. Number of feedings of nestlings by male and female per hour in C. mexicanus and C. pallasii.

\begin{tabular}{|c|c|c|c|c|}
\hline Date & Time & $\begin{array}{l}\text { Age of oldest } \\
\text { young (days) }\end{array}$ & \multicolumn{2}{|c|}{$\begin{array}{l}\text { No. of feedings } \\
\text { in one hour }\end{array}$} \\
\hline & & & \multicolumn{2}{|c|}{ C. mexicanus } \\
\hline $5-14-77$ & 1000 & 2 & & 2 \\
\hline \multirow[t]{2}{*}{$5-17-77$} & 1000 & 5 & & 5 \\
\hline & 1100 & & & 5 \\
\hline $5-21-77$ & 1500 & $9^{*}$ & & 3 \\
\hline \multirow[t]{2}{*}{$6-1-77$} & 1000 & $20^{* *}$ & & 3 \\
\hline & 1100 & & & 2 \\
\hline \multirow[t]{2}{*}{ Average } & $\ldots \ldots$ & $\cdots \cdot$ & $\ldots \ldots$ & $\ldots$ \\
\hline & & & \multicolumn{2}{|c|}{ C. pallasii } \\
\hline $2-27-78$ & 1100 & 1 & 3 & 4 \\
\hline $3-9-78$ & 1200 & 10 & 8 & 10 \\
\hline $3-12-78$ & 1000 & 13 & 11 & 9 \\
\hline $3-14-78$ & 1100 & 15 & 7 & 8 \\
\hline $3-18-78$ & 1100 & 19 & 5 & 6 \\
\hline $3-23-78$ & 1200 & 24 & 3 & $13^{* * *}$ \\
\hline Average & & & 7 & 9 \\
\hline * two youn & & & & \\
\hline ** one youn & & & & \\
\hline$* * * 8$ feedings & Iglings & & & \\
\hline
\end{tabular}

\section{Care of Nestlings}

Male and female dippers usually join in feeding the young (Hann 1950), but in this case, since the male in Territory II was not present, the female was left to brood and feed her young alone. During the first week after hatching, the female spent periods of 20 minutes to 1 hour brooding her young. Trips back and forth to the nest with food for the young were made as often as every 2 to 5 minutes, with periods of 10 to 20 minutes away from the nest to rest and feed herself. In this manner the young were fed three to five times per hour (Table 4).

During the second week in the nest, the female usually fed the nestlings as often as five times in 20 minutes, with longer periods of rest between feedings, so that she was still making about five trips per hour to the nest. She spent little time in the nest during the second week after hatching.

Occasionally, when the water level rose, she had trouble flying to the nest because of increased spray obscuring the entrance to the nest. She often clung to the outside of the nest while the young stuck their heads out to obtain the food.

Only two of the four nestlings survived to be banded at the age of 9 days. Only one survived to the age of 3 weeks, at which time it was ready to leave the nest.

Behavior of Fledglings

No observations were made of fledgling behavior. The eggs in the nest of M155 and F311 did not hatch because the parents were either killed or frightened away shortly 
after egg-laying when they were used for target practice by four men. Neither the one fledgling from the second nest nor its mother were seen after the young left the nest, possibly because the rapidly falling water level forced them to leave for an area with water in which to feed.

\section{Reproductive Behavior of Cinclus pallasii}

\section{Study area and methods}

The study area included a $2 \mathrm{~km}$ stretch of Hayakawa River in Hakone National Park, Japan, about $80 \mathrm{~km}$ southwest of Tokyo in Kanagawa Prefecture at an altitude of about $700 \mathrm{~m}$ (Fig. 5). The river was from 4 to $8 \mathrm{~m}$ wide, with many man-made falls along its course. The river was not in its natural state in some sections, since the banks were reinforced against flooding with stones and cement and were very steep. The natural bank still existed along other sections.

Dominant macrovegetation consisted of willow (Salix sp.), maple (Acer palmatum), alder (Alnus sp.), and dogwood (Cornus kousa). In one section of the study area the water was very calm, with reeds and grasses but no trees along the banks. The rest the water was fast flowing, with many large boulders in the river bed and groves of trees along the banks.

I visited the study area twice a week from February through May. When dippers were located in territories, mist nets were set across the river. Each captured bird was weighed, measured, and marked with a Japanese government band and plastic color band on the left leg and two plastic color bands on the right. Colors were assigned numbers as follows: $0=$ white or aluminum, $1=$ yellow, $2=$ orange, $3=$ red, $4=$ green, $5=$ blue, $6=$ purple. Observations were then concentrated on the occupants of two adjoining territories. Descriptions of these territories follow.

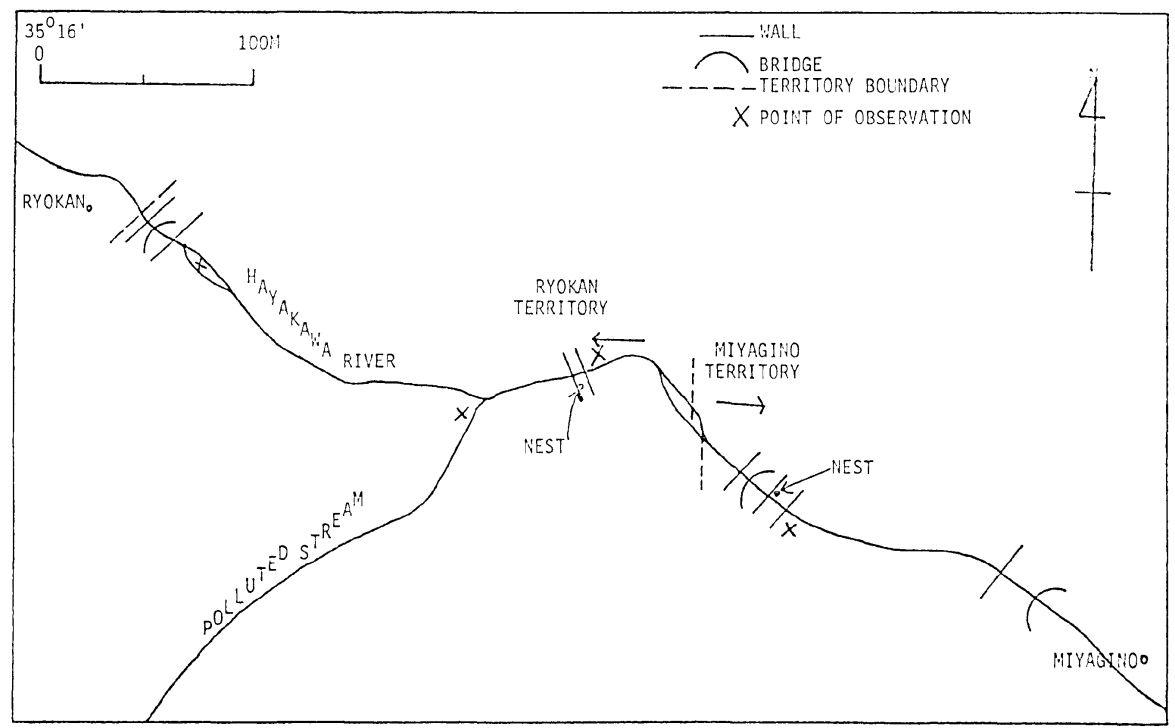

Fig. 5. Study area on Hayakawa River, Hakone National Park, Japan, in 1978. 


\section{Ryokan Territory}

This territory was so named because of a Japanese inn, or ryokan, located at its upper end. Just below the ryokan was a $300 \mathrm{~m}$ stretch of slow shallow water with no large rocks; the shallow banks were covered with reeds and grass. About $150 \mathrm{~m}$ below this section, a small stream entered the river, and at this point, from the end of March through the end of the study, pollution poured into the river, probably originating at the ryokan. After the pollution appeared, feeding was more frequent in the water above the small stream, though some feeding still occurred in the polluted area. The slow, shallow stretch of the river ended at a man-made waterfall formed by a rock wall about $15 \mathrm{~m}$ high. The nest of a pair of dippers was located in a square hole in the wall onethird of the way from the top of the falls. On either side of, and perpendicular to the falls was a rock wall about $7 \mathrm{~m}$ high. Below the falls lay a large, shallow pool that fed another falls about $0.5 \mathrm{~m}$ high. The river continued about $100 \mathrm{~m}$, made a $90^{\circ}$ bend to the right, and divided around an island. The right fork and the first half of the left fork was included in the Ryokan Territory (Fig. 5). Most of the dipper activity occurred in the middle to lower part of this territory.

\section{Miyagino Territory}

Named after the town located at one end, this territory began at the end of the island mentioned above. Another stone wall formed falls about $5 \mathrm{~m}$ high, below which the river became wide and calm. At this point, there was a car bridge, and below that, a $10 \mathrm{~m}$ falls formed by a wall that contained the nest of a pair of dippers about twothirds of the way from the top. Below the falls lay a shallow pool, another $0.5 \mathrm{~m}$ high falls, followed by a $100 \mathrm{~m}$ stretch of water strewn with boulders, and then a third wall which formed a $5 \mathrm{~m}$ falls. The territory continued beyond the last falls for approximately $500 \mathrm{~m}$, with many boulders but few trees along the banks; this boundary was the edge of the town of Miyagino. The pair of dippers rested or fed in this area, but most territorial and courtship behavior occurred in its upper stretches. The water in this territory was polluted by the same source as the Ryokan Territory.

I chose locations in each area where I could be concealed and still see that part of the birds' territories where most activities occurred. Most observations were during early morning, the most active time of day for dippers. Two to 3 hours were spent at each territory during each visit. Activities were viewed through $7 \times 21$ binoculars and accounts recorded on a cassette tape. Special attention was paid to territorial, pairing, and courtship behavior.

\section{Observations}

Territoriality

The most obvious territorial behavior was the rapid pursuit of an intruder. The flight was high over the river, as contrasted to the normal flight that took place very close to the water, and was accompanied by loud continuous calling. When the chase ended, the territory holder generally returned to the center, or most active part, of its territory to stay on guard momentarily before retiring to feed or rest. The territory holder also declared its possession of the territory by singing from a favored perch in the prime 
nesting area of the territory.

Territorial behavior was first observed on 1 February, when a territorial defense flight was seen in the Ryokan Territory. Earlier, three dippers were seen feeding together, but only two of them participated in the chase. Both flew high over the river, calling loudly as they flew.

Once territorial boundaries were established, only one territorial confrontation between neighbors was seen. On 16 February, the male of the Miyagino Territory, M555, chased the neighboring pair from the Ryokan Territory back upstream. This territorial flight differed from normal flight in that all three birds circled over the trees rather than staying over the river. M555 returned by flying over the trees and perched briefly in a tree before returning to the top of the dam above the nest. His mate did not participate in the chase because she was downstream at the time.

\section{Pairing Behavior}

Dippers were considered paired when one bird accepted another in its territory without any display of aggression. This was apparent when two were seen feeding, resting, or preening near each other or flying low together over the river without continuous calling as in territorial pursuits. Both birds picked up and carried nesting materials around the territory during this time.

Pair formation had just begun when I started collecting data on 1 February 1978 (Fig. 6). A pair was seen upstream from the ryokan for the first 2 weeks of February, but did not nest in that area, probably because of frequent human disturbance. Three dippers were seen below the ryokan. Most of the time all three flew and fed together, but on several occasion, two of the three would call and fly high over the river, which suggested a territorial defense flight, though territories may not have been established

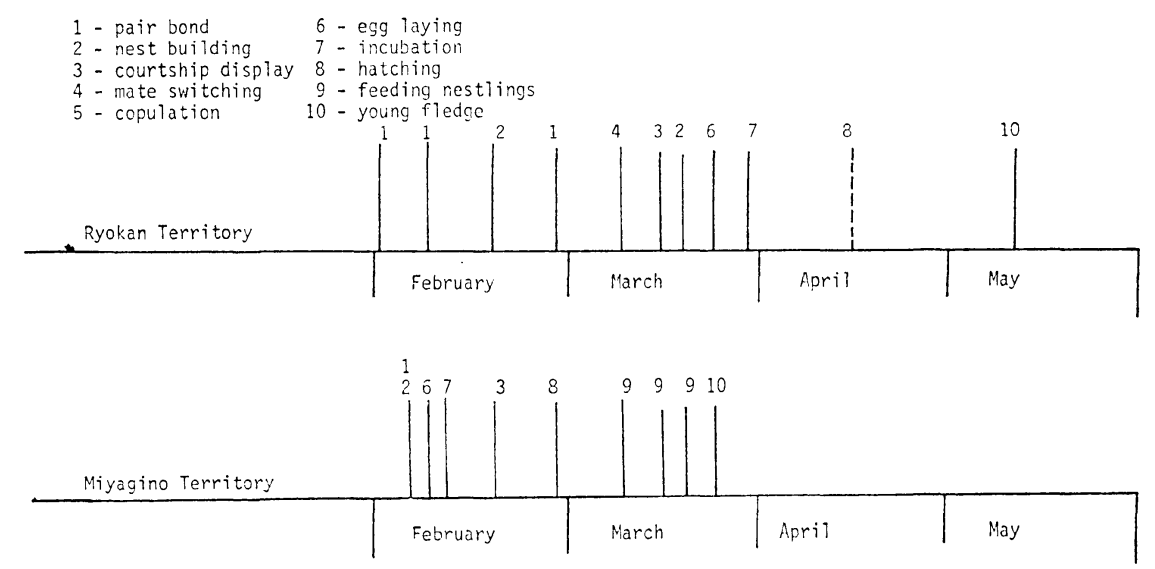

Fig. 6. Occurrence of phases of reproductive behavior in C. pallasii from February through May, 1978 in two adjoining territories on Hayakawa River, Hakone, Japan. Note total asynchrony in female reproductive cycles, which would allow for greatest amount of male help to occur staggered (between 8: hatching, and 10: fledging) should polygyny exist. Broken line indicates calculated dates for behavior to occur when they were not observed. 
yet.

Individual identification was difficult for the first month of observations while I awaited permission from the Japanese government to band the birds, but one of the three (F033) was previously banded by the Japanese ornithologist, Abe. Determination of sex was also difficult, but the banded individual was probably a female since it later stayed just below the ryokan at the upper edge of M555's territory, and there was no territorial pursuit between these two, which would have been expected had both birds been males. In fact, they shared a roost under a large boulder during the time M555 was involved in paired behavior with two other females. However, no nest was found in this part of the territory.

Now that F033 had settled in the upper Ryokan Territory, the other two dippers remained in the lower three-quarters of the territory and were joined by F044, also banded previously by Abe. The strongest pair behavior occurred between the two unbanded dippers, however. Both of them sometimes carried nesting material as they flew around the territory and fed close to each other.

The pair occupying the Miyagino Territory, later banded M333 and F000, were first seen as a pair on 5 February, but most likely had formed a pair-bond much earlier, judging from their stage of nestbuilding. The female was making occasional trips to the nest site, a hole in the man-made wall forming the falls, and both birds occasionally picked up leaves and shook them before dropping them.

\section{Nest Construction}

Generally, nest construction took place in the same manner in both the Miyagino and Ryokan Territories. After the appearance of pairing behavior, the female began collecting nesting materials of moss, leaves, and grass and constructing a nest. During nest building, the male accompanied her to and from the nest. He occasionally was seen with nesting material in his mouth, but never participated in carrying nesting material to the nest. Other researches have reported male help in building the outer portion of the nest (Henderson 1908, Rankin and Rankin 1940), but it was not observed in this study.

While the female carried material to the nest, the male chose a perch (often the one used to declare his territory) and began to spend much of his time in the area immediately surrounding the nest. From time to time, he flew into the nest for a short visit of 1 to 2 minutes. Completion of the nest required from 2 to 4 weeks. During the nest building phase of behavior, both birds became more responsive to intruders and defended the nesting territory more vigorously.

In the Miyagino Territory, F000 was first seen carrying material to the nest on 5 February. Eggs were laid shortly thereafter, suggesting that the lining was almost finished when first observed (Fig. 6).

In the Ryokan Territory, nest building began on 19 February, but the nest building did not proceed very rapidly. Several times the female dropped nesting material before reaching the nest. Often, she gathered several leaves a once, but dropped them before flying. She appeared to be either inexperienced or not highly motivated to build a nest at this time. On 27 February, the female was still working on nest construction, and 
was completing more trips to the nest with material than previously.

\section{Mate Switching}

Positive identification of individuals was difficult for part of these observations as I had not yet obtained permission to band the dippers. However, when a pair was seen together I was able to distinguish sex by body size, the male being about $8 \%$ larger than the female (Figure 2). Even though the birds were not yet marked I have referred to the male as M555, taking for granted that the same male retained this territory throughout the breeding season. The unbanded female of the territory will be referred to as FU; the second female was banded by the Japanese ornithologist, Abe as F044.

The following sequence of events was observed in the Ryokan Territory on 27 February; M555 was sitting on top of the opening, when a third dipper appeared from upstream. M555 and FU chased the intruder downstream. A few minutes later two dippers, M555 and F044, were perched on top of the dam. A third dipper flew into the area and another chase ensued, including all three birds. M555 and FU returned to the top of the dam and FU began collecting nesting materials again. She flew into the nest, then back out and upstream. When she returned, she was engaged in a chase with another dipper, which I was unable to identify.

For the next 2 hours, M555, F044, and FU remained together in the territory. Several chases involving any two of the three birds occurred, but it was impossible to identify those involved in each chase. The chases consisted of high circles over the nest area, accompanied by loud continuous calling. The third bird was not always in sight, but when it was, it was usually perched on the dam above the nest and was one of the unbanded ones, probably the male, since observations of C. mexicanus in 1977 suggested that most of the circle display flights involved the two females.

On 9 March, only two birds were seen in the nest area of the Ryokan Territory, but certain identification of the female was impossible. However, on 14 March the female was identified; M555 had switched from FU (now banded F111) to F044.

\section{Courtship Display}

The vertical stretch display exhibited by $C$. mexicanus was noted only once in $C$. pallasii. It was performed by the pair, M333 and F000, of the Miyagino Territory during the incubation period, and probably served a purpose other than courtship, perhaps possible pair-bond strengthening.

Courtship displays for $C$. pallasii included the circular display flight, as described for $C$. mexicanus, and what I called the horizontal stretch display, which was observed on 14 March. This display was clearly seen once on this day and was performed while both birds were perched low in a tree on the river bank. M555 and F044 were perched facing each other about $0.5 \mathrm{~m}$ apart on a horizontal branch. Both birds held their heads and tails low so that their bodies were parallel with the branch. Their wings were held perpendicular to their bodies and rapidly fluttered in a lateral motion, as compared to the up and down motion of flying. The male then turned $180^{\circ}$ with his back to the female and continued to flutter his wings. He then turned $90^{\circ}$, and remained in this position for less than a minute before turning once more to face the female, all the time fluttering his wings. During the entire time the female remained in the same position, fluttering 
her wings. Then they began to move closer, but prior to contact, they flew to the bank below the tree, and again began to flutter their wings and move together. Just as they were approaching each other the display was interrupted by the appearance of F111 (previously referred to as FU). Parts of this display were seen several more times during the day, but copulation was never observed.

\section{Incubation}

The female took total responsibility for incubating the eggs, which took about 15 days to hatch (Fig. 6). She spent from 30 to 60 minutes in the nest and 10 to 20 minutes out of the nest feeding. Once during this time out of the nest, the Miyagino pair engaged in a display similar to the vertical stretch display seen in C. mexicanus.

During the female's incubation periods, the male usually was on a nearby perch, as if he was guarding the nest area. He refrained from calling or singing, and when he left the nest area, it was only for 10 to 15 minutes. Occasionally, he carried food to the female in the nest.

Care of Nestlings

By 26 February, the eggs of the Miyagino Territory had hatched. Though the female was brooding the young during the first week, the parents each made about the same number of trips to the nest with food. From the time the nestlings were 10 days old until they left the nest, the male averaged seven trips, and the female nine trips to the nest per hour to feed the young (Table 4). Intervals between feedings ranged from 30 seconds to 16 minutes.

Apparently, F000 had trouble flying through the opening in the pipe to the nest, as she sometimes flew into the wall beside the hole and fell to the water below, but kept trying until she succeeded in reaching the nest. When banded on 6 March, the top of her head was devoid of feathers, I presume from flying into the wall. Three weeks later she was captured and examined again. By this time she was better at flying into the hole and feathers had begun to grow back.

\section{Behavior of Fledglings}

On 23 March, two young of the Miyagino Territory left the nest. The first few days out of the nest, the young stayed under or near large boulders or similarly protected areas. The female continued to feed them occasionally for another week. The male, however, did not feed them after they left the nest, but continued to feed the young that remained in the nest, while the female, making occasional trips to the nest, usually carried food to the fledglings on the rocks below.

As soon as the female came within their sight, the fledglings began to beg. They did not react to the male after they had left the nest. The begging posture was very similar to the horizontal courtship display. The wings were fluttered out to the side, but the tail was held over the back and the mouth was open.

Gradually, the young stopped begging and started catching their own food. Within a week, they had lost most of their clumsiness and were almost as skilled at collecting food as their parents.

Only two fledglings were seen in the territory, though I assume there was at least one other nestling, since the male carried food to the nest after the two young had fledged. 
Seven to 10 days after leaving the nest, the two fledglings were gone from the territory. Second Brood

On 31 March, just a few days before the fledglings left the territory, M333 and F000 performed what appeared to be a variation of the horizontal stretch display, The pair was above the dam on a large flat boulder, the female fluttered her wings in the horizontal stretch position while the male mounted her for about 5 seconds, without any wingfluttering. At the end of the display, both birds flew to the top of the dam.

On 13 April, F000 was once more carrying leaves into the same nest as before. On 27 April, the male carried food to the nest, probably to the incubating female, but by 11 May, the pair were spending an hour and 30 minutes out of the nest. The female made several short trips of around 1 minute to the nest but was not observed to carry any food. The eggs should have hatched by then, and the female should have still been brooding the majority of the time, so I assumed that the attempt to raise a second brood was unsuccessful. (The study was terminated at this point.)

\section{Behaviors}

\section{Discussion}

Stejneger (1905) stated that the ancestral dipper as early as the Miocene had acquired the characteristics common to the entire modern family. At the present time, there are only slight physical diffeences between species and they all fill similar niches in similar geographically distinct regions. Though only two of the four species were studied here, the similarities in behavior of $C$. mexicanus and $C$. pallasii, along with similarities noted in literature on $C$. cinclus, leads me to believe that conclusions drawn for $C$. mexicanus and $C$. pallasii could be extended to include the entire family.

\section{Territoriality}

The size of territories varies greatly among the three species of Cinclus most frequently studied. (Literature on $C$. leucocephalus is almost nonexistent.) Sunquist (1974) reported an average size of $425 \mathrm{~m}$ of stream length, for $C$. pallasii, which corresponds with my findings. Robson (1956) reported an average of 470 yds $(430 \mathrm{~m})$ for C. cinclus whereas Balat (1964) found territory sizes ranging from 290 to $1850 \mathrm{~m}$. Hann (1950) reported territories for C. mexicanus of around 0.5 miles $(805 \mathrm{~m})$, which corresponds with my findings for that species in California. Although the territories observed in Japan were the same size as those reported for C. pallasii elsewhere (Sunquist, 1974), the nests observed in Japan were closer together than any reported for C. mexicanus but corresponded with that reported for C. cinclus (Balat, 1964).

The habitats occupied during the reproductive season were similar in C. mexicanus and $C$. pallasii. Latitudes of the two study areas were within two degrees of each other and there was a difference of $200 \mathrm{~m}$ in altitude, resulting in similar climates with temperatures usually between $0^{\circ} \mathrm{C}$ and $10^{\circ} \mathrm{C}$. Both areas were frequented by man, and contained man-made dams. These similarities in habitats may be partially responsible for the similarities in mating systems observed. Had either study been conducted in a setting farther from the influences of man, the more common, monogamous mating system may have occurred exclusively (see Hann 1950). Bridges, dams, and fish hat- 
cheries change the distribution of nesting sites and feeding areas, which increases the potential for polygyny. (This idea is explained further in the discussion of mating systems.) Further research on this theory would be helpful in determining the reasons for the occasional presence of a polygynous mating system in dippers.

In both species studied, territories were established in January and February. Defense was by means of the territorial defense flight described earlier in this paper. Bakus (1959b) reported that there was no territorial defense after the transition from what he called winter territorial defense, occurring November through February, to pairing and nesting. However, territorial disputes probably lasted well into the nesting season.

\section{Courtship Displays}

There are almost as many interpretations of courtship displays as there are studies of Cinclus. The vertical stretch display described in this study was also described by Bakus (1959b) who interpreted it as territorial defense. Though agonistic displays are very often similar to sexual displays (Selander 1972), I believe, as do others (Serle and Bryson 1935, Hewson 1967, Sunquist 1974), that the performance of this particular display indicates a courting pair, and may in some cases act as a strengthening of the pair bound, as when performed after a territorial defense flight or during incubation. The study on $C$. cinclus by Hewson (1967) showed that the "upright posture" was performed by the male, while the female counterpart was "bobbing and wing-flicking" or dipping. In the present study and in others (Steiger 1940, Bent 1948), dipping was seen at all times of the year, including the nesting season, by solitary birds, even while feeding, and was considered independant of any sexual behavior.

The horizontal stretch display as described in this study has not been reported elsewhere; however, variations have been. Rankin and Rankin (1940) reported wing shivering in $C$. cinclus in which the wings were held half open and out from the body, and bowing, with the head raised and lowered while the wings were vibrated. Hewson (1967 citing Witherby, unpublished field notes) reported the same display, and Goodge (1959) reported wing fluttering accompanied by courtship feeding. Why there should be so much variation among courtship displays is a puzzle, but may be more a matter of difference in description and interpretation of what occurred than actual differences in displays.

The display flight has been reported by several researchers (Muir 1894, Moody 1955, Hewson 1967, Sunquist 1974), and was considered by most to be a courtship display. However, the question of agonistic versus sexual displays appears again. Grzimek (1977) defines a display behavior as being a threatening behavior that repels same sexed rivals and attracts members of the opposite sex. In the present study, the display flight was often performed by two females, both trying to occupy the same male's territory, but at times, the male joined in the flight, a clear example of a display behavior.

\section{Mate Switching}

Since mate switching occurred in both of the present studies, I consider it to be a significant part of the mating system of Cinclus, at least under circumstances such as were seen here, where man had affected the habitat with his presence and the presence 
of man-made dams. Mate switching has been reported only two other times in the literature on Cinclus (Bakus 1959b, Morse 1979), possibly because most observations were on unmarked individuals, or they were made in areas not altered as much by man. Nest Construction

In the present study the males of both species were not seen to take part in building the nest. This may indicate that the pairs I observed were using previously built nests, as Rankin and Rankin (1940) reported that the male helps build the outside of the nest but only the female builds the inside. Others (Henderson 1908, Hewson 1967) also reported the male helping with the nest, but did not specify whether he helped with the outside only or the entire nest. They may have seen the male carrying nesting material around the territory and concluded he was helping to build the nest. In the present study the male did sometimes carry nesting material as he flew around the territory. Though he did enter the nest during nest building, he was never seen contributing material to the nest.

\section{Incubation}

Incubation is performed solely by the female, although the male may feed the female in the nest. Hann (1950) reported that the male fed the female as many as seven times in one incubation period. In the present study, the length of time the female C. mexicanus spent on the nest and away from it is shown in Table 3, along with a comparison of reports by Goodge (1959) and Hann (1950) for the same species. Goodge reported shorter periods of 32 to 34 minutes on the nest and 7 to 10 minutes off, whereas Hann reported much longer incubation periods of up to 80 minutes, with 12 to 21 minutes away from the nest. Although the female I observed was alone (Territory II), she stayed as long or longer than the accompanied females observed by Goodge and Hann, indicating that a polygynously mated female could successfully maintain the clutch without the full help of a male. The type of nest utilized by the dipper aids in allowing the female to maintain the clutch alone, as the closed nest allows for greated protection from predators and reduction in heat loss while the female is off the nest.

Care of Young

The female broods the young for the first week or so since young dippers are poikilothermic. Hann (1950) reported brooding periods of 5 to 61 minutes usually not more than 25 minutes for the first few days, and stated that the male never entered nest. The males in the present studies en'ered the nest to feed the young but did not brood them.

A possible explanation for the presence of poikilothermy in young altricial birds, as opposed to homeothermy in young precocial birds, was given by Whittow (1970). He proposed that poikilothermy is a functional adaptation related to the physiological energetics of small animals. If not used for producing body heat to maintain homeostasis, the energy can be used for more rapid growth and development.

Table 4 shows the number of feedings by male and female and number of young successfully fledged by the Miyagino pair and the single female $C$. mexicanus. Success rate for each nest averaged one fledgling per adult for both the pair and the single female. Since the female, with reduced male help showed the same success rate per 
adult as a monogamously mated pair, I would expect a polygynously mated male with his females to average at least one fledgling per adult. Price and Bock (1973) found the success rate to be higher in polygynously mated dippers than in monogamous pairs, and suggested this was partially due to extended feeding areas held by polygynous males because of lack of nest sites in adjacent areas.

Second Brood

The Miyagino pair appeared to have started a second brood though it is questionable whether any were successfully fledged, since fledglings were not observed in the area after the first brood left. Balat (1964) found that if the winter was mild, allowing nesting to begin early, it was likely that dippers would have a second brood, and Price and Bock (1973) reported seeing two successful broods; but other investigators reported no instances of second broods (Hann 1950, Goodge 1959). The elevation of the nest site, which correlates with the earliness of the spring season, probably affects conditions, such as ice cover on the river and availability of food, that determine whether the dippers can begin nesting early enough in the season to have time left after the first brood to raise a second one. At elevations where ice cover is no problem, nesting may begin earlier than at higher elevations, but there may exist the chance of streams drying up before a second brood could fledge (Morse 1979). Indications from the present study suggest that if there is enough time to raise another brood after the first one has fledged, the birds will attempt to do so.

\section{Cinclus Mating System}

The majority of studies have found the dipper to be monogamous. However, I believe dippers are well adapted to using a polygynous mating system. Price and Bock (1973) reported several cases of successful polygyny in C. mexicanus. In the present study a male was observed to copulate with two females on the same day, while both females were present. This occurred after switching mates during the nest building phase. C. pallasii was also observed switching mates in the present study, and several other cases in the literature report activities that suggest possible mate switching and/or polygyny (Muir 1894, Serle and Bryson 1935, Bakus 1959b, Balat 1962, Morse 1979). The birds were not marked in most cases, so such conclusions on mating system could not be drawn. However, after twice observing the same sequence of events in mate switching with marked individuals, I recognize striking similarities in behaviors reported by others, which support my findings on mate switching and possible polygyny. For example, Bakus (1959a) reported the following ([?] indicates that I question the sex);

An unbanded male [?] Dipper was heard singing loudly for 10 minutes. Bird $\$ 7$, a male, approached him and both assumed a territorial defense posture. Then the unbanded male [?], with wings bent downward, shook them rapidly, reminiscent of shivering in man when cold. A third Dipper approached and all three birds walked in a two-foot circle while maintaining territorial defense postures. The third bird, presumably a female, had been observed with $\sharp 7$ before he approached the singing male [?]. Next, $\$ 7$ chased the male [?] 50 yards upstream, the female following behind. All three birds returned downstream several minutes later. 
The unbanded male [?] sang very loudly and shook his wings. Number 7 then shook his wings and gave a repeated alarm call. The female stood off to one side and watched the display. The chase resumed again as $\$ 7$ pursued the male [?] upstream and the female followed them. This behavior continued for another 30 minutes. The unmarked male and female were banded ( $\$ 23$ and $\$ 24)$ but their sex could not be determined at the time of marking.

In November 1959, Bakus reported:

In the spring of 1957 birds no. 23 and 24 were banded on March 9. On the same day, previous to the marking of these two, the first observed pairing of brids occurred between no. 7 and either no. 23 or 24 . However, this was temporary as no. 7 was seen to be paired with an unbanded bird on March 28. This indicated that some birds may change mates during the early pairing period.

Bakus (pers. comm., 1979) agreed that $\# 23$ and $\# 24$ could have been females. So \#7 could have been, at one time or another, paired with three different birds; $\$ 23$, $\# 24$, and the unbanded one. Number 7 was not observed participating in polygynous mating, however.

\section{Monogamy vs. Polygyny}

Monogamy was defined by Lack (1968) as that system in which male and female stay together through one brood, and by Emlen and Oring (1977) as the system in which neither sex has the opportunity to monopolize additional members of the opposite sex. Polygyny occurs when one male has a pair bond with two or more females either simultaneously (harem polygyny) or in succession (successive polygyny) (Lack, 1968). Emlen and Oring (1977) considered polygyny as occurring when an individual male controls or gains access to more than one female, either indirectly by monopolizing critical resources (resource defense polygyny) or directly through control of the females themselves (female or harem defense polygyny). Successive polygyny may describe what was observed in mate switching, but resource defense polygyny better describes the Cinclus mating system.

Monogamy is the dominant avian mating system. occurring in more than $90 \%$ of the species studied (Lack, 1968). The main advantage to monogamy is that two parents can feed the young and so raise more off-spring than the female alone. At the same time, a monogamous male should be under the selective pressure to pursue a mixed reproductive strategy, that is, to help a single female raise young while not passing up the chance to mate with other females (Trivers, 1972). If the extra females stay in the territory of the male, polygyny exists.

Polygyny is advantageous to the male if the female can raise the young alone since he can increase his gene flow in the population. Disadvantages to the male, however, include: (1) a greater demand for territorial defense, (2) greater chance of death since he becomes more conspicuous while increasing territorial defense, (3) lowered reproductive success per female due to reduced male help (no relationship between clutch size and mating system has been found: Skutch 1949, Haartman 1954, Klomp 1970, all 
cited by Selander 1972), (4) greater risk of stolen copulations so that he may spend his energy rearing another male's young (Verner 1964).

The advantage of polygyny to the female is an increased probability of breeding in the best possible area with a genetically superior male. At the same time, she will receive less of the male's help in raising the young, and have a smaller foraging area.

Two preconditions must exist for polygyny to occur (Emlen and Oring, 1977): (1) the male must be able to defend multiple mates, or resources, such as food and nesting sites, sufficient to attract multiple mates. In an aquatic environment, for example, food is continuously replenished and fairly evenly distributed (Orians, 1969), but nesting sites may be concentrated so that one male is able to defend a large enough percentage of the total available nesting sites to attract more than one female to his territory. (2) The degree of parental care required for successful rearing of young must guarantee that the species can take advantage of the polygyny potential of the environment, the degree to which the environment is suited to polygyny.

Two factors may increase the polygyny potential for a species. Polygyny can

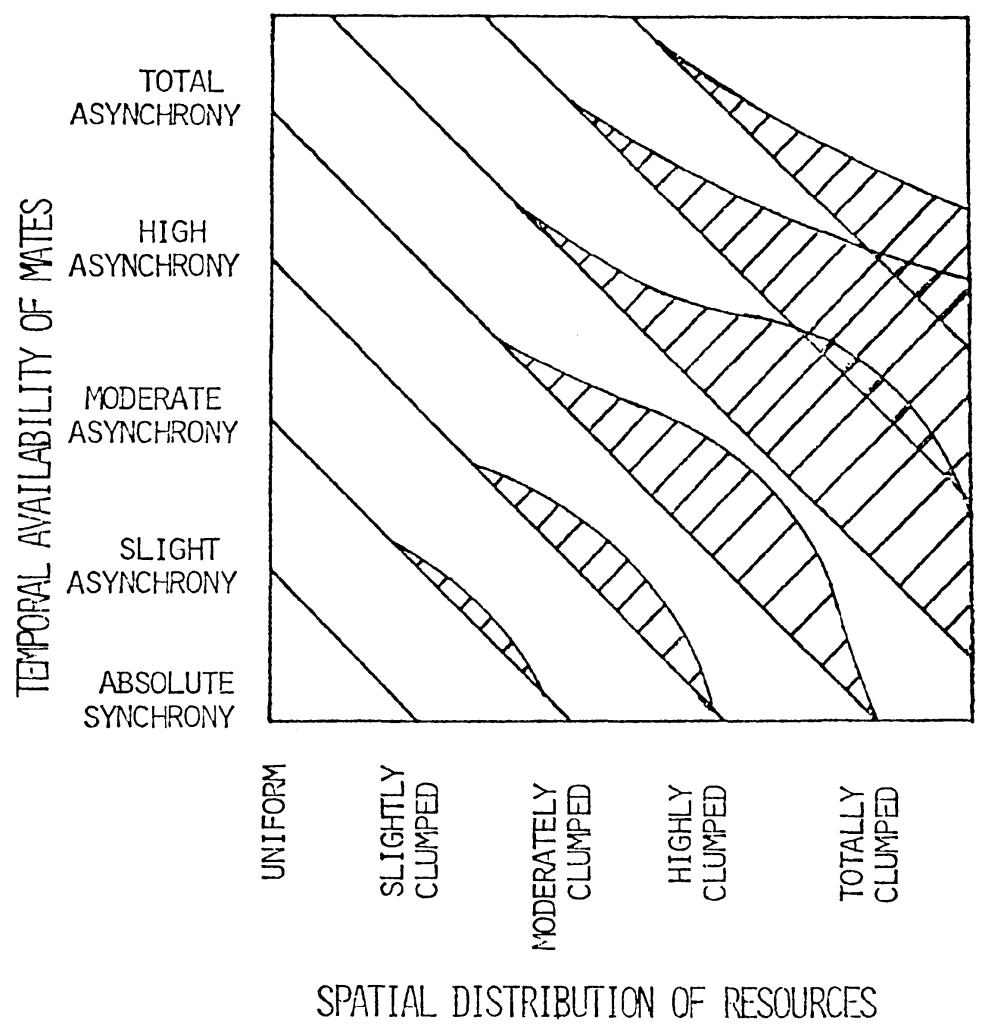

Fig. 7. Three-dimensional model illustrating the polygyny potential of an evnironment from Emlen and Oring (1977). The graph shows the relation of the polygyny potential, represented by perpendicular height of the shaded area, to spatial distribution of critical resources (nesting sites, food) and the asynchrony of reproductive cycles of available mates. 


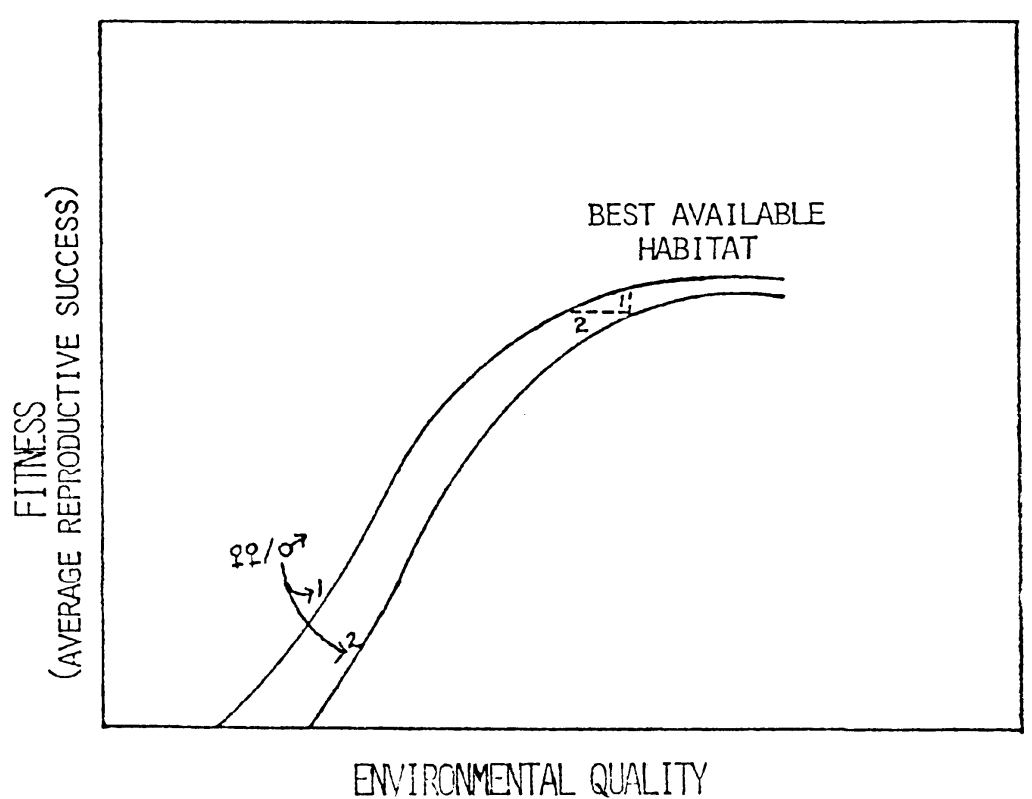

Fig. 8. Orians's (1969) model depicting the polygyny threshold of a species (distance 2). Distance 1 shows the difference in fitness between females mated monogamously and polygynously in the same environment. The polygyny threshold is defined as the difference between two males' territories to such a degree as to allow a female to rear more offspring alone on a better territory, than would be possible on the poorer territory, even with male help (Verner and Willson 1966).

occur if environmental or behavioral conditions bring about concentrations of females in a territory, and the males have the capacity to attract, defend, and maintain them (Emlen and Oring 1977). When food and nesting sites are unevenly distributed, or spatially clumped, certain males can control a greater percentage of these resources (Fig. 7). If these resources are critical for female reproduction, the female choice of a mate should depend not only on the genetic quality of the defending male but on the quality of the territory he controls. The extent of difference in quality between territories that is sufficient to favor polygyny will vary with such factors as (1) distribution of male parental care among the young of his various mates, (2) total amount of parental care required by the young, (3) degree of dependency on territory itself (e.g., just for nesting or also for feeding) (Emlen and Oring 1977). Orians (1969) illustrated the effect of environmental variation on the mating system of a species, and refers to the minimum difference in quality of males' territories sufficient to favor polygyny as the polygyny threshold (Fig. 8).

The second factor that may act to increase the polygyny potential of a species is a large degree of asynchrony among females' reproductive cycles (Fig. 7). The greater the asynchrony, the greater the number of females the male will have time to help per season (Emlen and Oring 1977).

The presence or absence of polygyny in a population is also determined by its 
advantages or disadvantages to the female, since she has the most to lose in terms of energy spent producing gametes. She is the one that makes the choice of mates, and it is to her benefit to choose a mate which controls a prime territory, even if he is already paired, rather than choose an unpaired male with a poor territory. When the male parental role in a species is extensive and involves possession of a territory that will supply all or a major part of the food for the young, the female should base her choice on an assessment of the quality of the territory and the probability that the male is capable of and disposed toward assuming parental duties (Orians 1969).

If the male can be relieved of parental duties to the degree that the female can successfully raise the young with greatly reduced male help, polygyny can occur. This is facilitated in closed-nesting (domed nests or nests in holes) species, such as dippers because: (1) the male is less important in driving off predators and covering eggs, (2) the safety of the nests makes relatively slow growth rates in nestlings possible, and (3) good insulation reduces maintenance costs of nestlings (Haartman 1969, cited by Selander 1972). A reduction in food required per unit time by nestlings reduces need for male assistance in parental care.

Many monogamous passerine species are preadapted, because of disparate parental investments, to respond to changes in their environment by becoming opportunistically or facultatively polygynous (Emlen and Oring 1977). Still, it is to the advantage of the female to have the territory and mate to herself, so that strong territorial defense against additional females may result. If she is successful in keeping out intruders, monogamy will persist; if the new female is stronger, a switch in mates may occur. However, as in the case viewed by Price and Bock (1973) for C. mexicanus, it is possible for both females to remain in the territory to nest. Mate switching, then, can provide a link between a generally monogamous mating system and polygyny.

Once polygyny is established in a population (polygyny is considered regular rather than casual by Verner and Willson (1969) when at least $5 \%$ of the males are polygynists), the degree of development depends on the range in quality of the territories and the extent of the male's role in raising the young (Holm 1973). Verner (1964) found that in the Long-billed Marsh Wren, harem size was limited to two females where the male fed the young, and three where he did not.

\section{Environment}

\section{How Cinclus Fits the Polygynous Mating System}

The habitat of the dipper is such that critical resources could easily be unevenly distributed through the environment. Acceptable nest sites are limited, and by their nature, are concentrated in areas where suitable rock faces and flowing water are found. In addition, the presence of man-made structures such as dams and bridges further act to clump nest sites, since the dipper readily uses man-made structures. Food resources appear to be fairly evenly distributed; however Thut (1970) reported that the majority of food items are found in slow-flowing areas, which would mean that food is not as evenly distributed as it might appear and may become even more unevenly distributed due to dams and fish hatcheries. Uneven distribution of these factors necessary for 
reproduction, could allow males to control prime territories containing proportionately more of these factors. Also, the male may feed away from the area surrounding the nest (Steiger 1940), which would leave more food immediately available to the females and young.

\section{Role of Male and Female in Caring for Young}

Dippers show disparate parental care in that the female alone incubates the eggs and both parents feed the young. The male can be further relieved of his duties because of the type of nest used by Cinclus. The domed nest allows protection and insulation the young need for slow growth, (24 to 26 days from hatching to fledging) so that less food per day is required. Other species of birds of similar size spend shorter periods of around 10 to 15 days in the nest before fledging (Wallace and Mahan 1975). The insulation of the closed nest could conceivably free the female early in the poikilothermic growth phase of the young, so that she can collect food for them. She is also free to

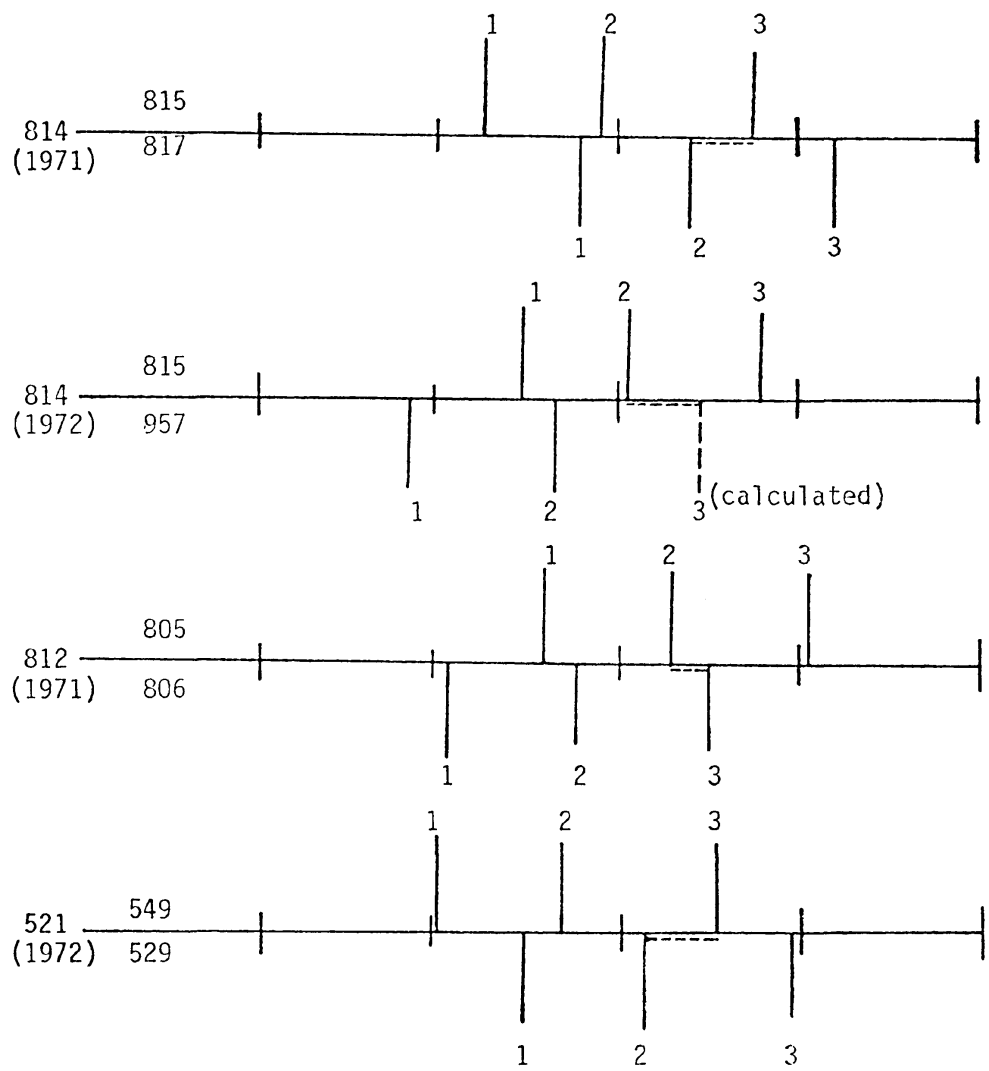

Fig. 9. Asynchrony in female reproductive cycles of polygynously mated C. mexicanus. Data are from Price and Bock (1973). 1 indicates date eggs were laid; 2, when they hatched, and 3, when the young fledged. Broken line indicates the overlap in time when male help is required by both females. 
leave the nest during incubation to feed herself, since the eggs will retain the heat longer than when placed in an open nest.

Asynchrony in Reproductive Cycles of Females

Judging from the time between nesting by the first pair and the last pair in this study, females are probably asynchronous in their reproductive cycles (Fig. 4 and Fig. 6), which allows a male to have more than one mate, each mate needing the greatest help in feeding the young at different times. Price and Bock (1973) did not mention the existence of asynchrony in polygynously mated females in their study, but their data show a significant amount of asynchrony in females' reproductive cycles to allow the male to concentrate his time feeding nestlings of one nest at a time (Fig. 9).

Sexual Dimorphism

Obvious sexual dimorphism in the form of showy feathers or colors does not exist in Cinclus, and probably will not evolve, as was suggested by Carey and Nolan (1975). Because of their method of feeding, showy feather would hinder the male to such a degree as to make him less fit evolutionarily. Cinclus does, however, use long vocal advertisements as would be expected of a territorial male competing for mates with his neighbors.

\section{Conclusions}

My observations on incubation and feeding of young by the single $C$. mexicanus and the monogamously paired $C$. pallasii (Table 3 and Table 4) show that it is possible for a single female to raise young alone. The number of successful offspring per nest was highest for the monogamous pair and monogamy should be the dominant mating system under natural circumstances; however, C. mexicanus and $C$. pallasii are well suited to a polygynous mating system, because of the type nest utilized, unequal parental investments, asynchrony in the reproductive cycles of females, and utilization of an aquatic food supply that is constantly replenished. As rapid changes, especially due to man, occur in their environment, causing critical nesting resources such as nest sites and food to become concentrated or limited, the dipper is able to become facultatively polygynous.

\section{Acknowledgments}

I would like to express my gratitude to my committee members, Dr. David Grubbs and Dr. Arthur Staebler for their help and guidance during this study. Special thanks goes to my committee chairman, Dr. Richard Haas for the extra time and effort necessary on his part because of the miles between us throughout most of the study.

I thank Dr. Gerald Walsh, Dr. Nelson Cooley, and Mr. Sam Tagatz for reviewing earlier drafts of this manuscript and giving valuable criticism.

Sincere thanks goes to Pam Morse for her help in the field in California and her moral support, and to Carol Merrill and Susie Brady for their untiring help in the field in Japan.

The Japanese government was very gracious in allowing me to band and study the birds in Hakone National Park. I thank Mr. Masashi Yoshii of the Yamashina Institute 
for Ornithology for his guidance in choosing a study area and assistance in receiving a banding permit. Special thanks is due Nobuko Shimokawa, my guide, translator, and friend. Finally, sincere thanks goes to my husband, Rory, who gave me continuous encouragement and support throughout the study.

Research in Japan was partially supported by a grant from the Frank M. Chapman Fund, for which I was very grateful.

\section{Summary}

Reproductive behavior of the Japanese dipper, Cinclus pallasii studied in spring, 1978 in Hakone National Park, Japan, and the American dipper, Cinclus mexicanus, studied in spring 1977 in the Sierra Nevadafoothills, California, are described and their mating systems examined. Similarities between the two species were as follows. 1) Both species were living in an area frequented by man, and in fact built their nests in man-made walls that formed dams. 2) Both species showed rigid territoriality, and rarely crossed the boundaries of their territories. Males and females engaged in territorial defense by means of the territorial defense flight. 3) The sequence of events during the reproductive season varied from what is usually seen in birds in that the pair bond was formed before courtship displays were performed. 4) The male of both species switched mates during the nest building phase. Both the old and new mate were later present together in the nest area when courtship and/or copulation took place, and in the case of $C$. mexicanus, the male copulated with both females. 5) Females showed partial asynchrony in reproductive cycles in adjoining territories.

Differences were also observed. 1) Nests were situated in adjoining territories so that they occurred closer together for $C$. pallasii than for C. mexicanus. 2) $C$. pallasii showed a greater tendancy to fly over land rather than to follow the course of the stream as $C$. mexicanus did. 3) The courtship display performed by $C$. mexicanus was what I called the vertical stretch display, while a horizontal stretch display was performed by $C$. pallasii. Both species performed the circular display flight.

I hypothesize that the striking similarities in reproductive behavior of $C$. mexicanus and $C$. pallasii are due largely to the similarities of the environment in this study, especially the effects man has on their habitat. The presence of man and his influences on the habitat through the building of dams, bridges, and fish hatcheries, works to limit or clump resources critical to the nesting behaviors of $C$. mexicanus and $C$. pallasii, especially nesting sites and feeding areas. This factor, along with the preadaptations of the two species of dippers for polygyny, through unequal parental care, the use of closed nests, allowing for less parental care, asynchrony in the reproductive cycles of females, and utilization of an aquatic food supply, allows these species to adopt a polygynous mating system. Inversely, since dippers are so well adapted to a polygynous mating system, they are able to cope with changes in their environment brought on by man.

\section{References}

Bakus, G. J. 1959a. Observations of the life history of the Dipper in Montana. Auk, 76: 190-207.

Bakus, G. J. 1959b. Territoriality, movements, and population density of the Dipper in Montana. Condor, 61 : 410-425.

Balat, F. 1962. Distribution and movements of the Dippers, Cinclus cinclus aquaticus Bescht, on a creek and their changes during a year. Zoologicke Listy, 11: 131-144.

Balat, F. 1964. Breeding biology and population dynamics in the Dipper. Zoologicke Listy, 13: 305-320.

Bent, A. C. 1948. Life histories of North American nuthatches, wrens, thrashers, and their allies. Bull.

U.S. Nat. Mus., 195: 96-113.

Brownlow, J. G. 1949. The underwater movements of the Dipper. British Birds, 42: 69-73.

Burgham, J. S. 1904. Notes on the habits of the Water Ouzel (Cinclus mexicanus). Condor, 6: 50. 
Carey, M. and Nolan, V. Jr. 1975. Polygyny in Indigo Buntings: a hypothesis tested. Science, 190: 1296-1297.

Cordier, A. H. 1927. Some observations on the Water Ouzel. Auk, 44: 169-178.

Ehinger, C. E. 1930. Some studies of the American Dipper or Water Ouzel. Auk, 47: 487-498.

Emlen, S. T. and Oring, L. W. 1977. Ecology, sexual selection, and the evolution of mating systems. Science, 197: 215-223.

Goodge, W. R. 1959. Locomotion and other behavior of the Dipper. Condor, 61: 4-17.

Grzimek, h.c.B. 1977. ed. Encyclopedia of Ethology. New York: Van Nostrand Reinhold Co.

Haartman, L. von. 1954. Der Trauerfliegenschnäpper. III. Acta. Zool. Fenn., 83: 1-96.

Haartman, L. von. 1969. Nest-site and evolution of polygamy in European Passerine birds. Ornis Fennica, 46: 1-12.

Hann, H. W. 1950. Nesting behavior of the American Dipper in Colorado. Condor, 52: 49-62.

Henderson, J. 1908. The American Dipper in Colorado. Bird-Lore, 10: 1-7.

Hewson, R. 1967. Territory, behavior and breeding of the Dipper in Banffshire. British Birds, 60: 244-252.

Holm, C. H. 1973. Breeding sex ratios, territoriality, and reproductive success in the Red-winged Blackbird (Agelauis phoeniceus). Ecology, 54: 356-365.

Ingram, G. C. S., Salmon, H. M. and Tucker, B. W. 1938. The movements of the Dipper under water. British Birds, 32: 58-63.

Klomp, H. 1970. The determination of clutch-size in birds: a review. Ardea, 58: 1-124.

Lack, D. 1968. Ecological Adaptations for Breeding in Birds. London: Methuen.

Moody, C. 1955. Display-flight of Dipper. British Birds, 48: 184.

Morse, P. J. 1979. Behavior of the Dipper, Cinclus mexicanus, on foothill streams of the Sierra Nevada, Fresno County, California. M.A. thesis, Cal. State Univ., Fresno. 96 p.

Muir, J. 1894. The Mountains of California. New York: The Century Co.

Orians, G. H. 1969. On the evolution of mating systems in birds and mammals. Amer. Nat., 103: 589-603.

Price, F. E. and Bock, C. E. 1973. Polygyny in the Dipper. Condor, 75: 457-486.

Rankin, M. N. and Rankin, D. H. 1940. The breeding behavior of the Irish Dipper. The Irish Naturalists' Journal, 7 : 273-282.

Robson, R. W. 1956. The breeding of the Dipper in North Westmorland. Bird Study, 3: 170-180.

Selander, R. D. 1972. Sexual selection and dimorphism in birds. In: Sexual Selection and the Descent of Man (Ed. by B. G. Campbell), pp. 180-230. Chicago: Aldine.

Serle, W. Jr. and Bryson, D. 1935. Distribution and number of the Dipper on the N. and S. Esks (Midlothian). British Birds, 28: 327-331.

Skinner, M. P. 1922. Notes on the Dipper in Yellowstone National Park. Condor, 24: 18-21.

Skutch, A. F. 1949. Do tropical birds rear as many young as they can nourish? Ibis, 91: 430-455.

Steiger, J. A. 1940. Dipper, wilderness dweller. Bird-Lore, 42: 10-14.

Stejneger, L. 1905. The birds of the genus Cinclus and their geographical distribution. Smithsonian Misc. Coll., 47: 421-430.

Sunquist, M. E. 1974. Territory size and nesting habits of Brown Dippers, Cinclus pallasii. Ibis, 118: 577-578.

Thut, R. N. 1970. Feeding habits of the Dipper in southwestern Washington, Condor, 72: 234-235.

Trivers, R. L. 1972. Parental investment and sexual selection. In: Sexual Selection and Descent of Man (Ed. by B. G. Campbell). pp. 136-179. Chicago: Aldine.

Verner, J. 1964. Evolution of polygamy in the Long-billed Marsh Wren. Evolution, 18: 252-261.

Verner, J. and Willson, M. F. 1969. Mating systems, sexual dimorphism, and the role of male North American passerine birds in the nesting cycle. Ornith. Monogr., No. 9: 1-76.

Wallace, G. J. and Mahan, H. D. 1975. An Introduction to Ornithology. Third ed. New York: Collier Macmillan.

Whittow, G. C. 1970. Comparative Physiology of Thermoregulation. Vol. I. New York: Academic Press. 


\section{カワガラス・メキシコカワガラス 2 種におけるー夫一妻 から一夫多妻制への適応的交代 \\ Donna Hansen}

1978 年春, 箱根国立公園で調査した日本のカワガラス，および 1977 年の春にカルフォルニアのシェ ラ山麓で調查したメキシュカワガラスの番構造について比較考察した。この 2 種の類似点は次の通りで ある。

1) 両種とも人がよく出入する地域に生息し，ダムの人工壁に営巣する。

2）両種とも国定したナワバリを有し，ナワバリの境界を出ることはほとんどない。雄，雌ともナワバ リ防衛飛行 (territorial defence flight) を行なら。

3）繁殖期に抢恀るこの行為は，番形成におけるコートシップディスプレイの前に，普通見られるもの とは異なっていた。

4) 両種とも雄は営巣の段階で, 橎いの相手を変えた。番いの前の相手と新しい相手は後でコートシッ プや交尾が行なわれる時に, 巣の地域に其に出現した。そしてメキシュカワガラスの場合雄は両方の雌と 交尾した。

5）隣接するナワバリ内の雌たちの繁殖サイクルに部分的非同時性が見られた。

両種に打ける相違点も観察された。

1）巣は隣接するナワバリ内にあるが，カワガラスのカがメキシュカワガラスより一層巣が接近してい た。

2) メキシコカリガラスは流れのコースに沿って飛ぶがカワガラスはをしろ，地上を飛ぶ做同がより大 きかった。

3) メキシコカリガラスが行ならコートシップディスプレイは著者が垂直伸びディスプレイと称するも のであるが，カワガラスではそれが水平伸びであった。ただし，雨種とも，周回詻示飛行を行なった。

著者はメキシコカワガラスとカワガラスの繁殖行動におけるこの著しい類似性はおおお拉本調査におけ る環境の類似によるものであり，特に人間がカワガラスの生息地におよぼした影響によるもの，と仮説す る。人間の近接抢よびダム，橋，養魚場の建設に上る生息地への影響は，メキシコカワガラスとカワガラ スの営巣行動, 特に営巣場所と採䬣地域に必要な自然資源を変更する働きをする。この環境要因に加え, これら 2 種のカワガラスは一夫多妻制への前適応をもっていたため,一夫多妻の配偶形式が可能となった。 この前適応性は，1）育雛上の仕事の性差と，2）安全なドーム形の閉鎖巣によって，1 羽の親の育雛労力 が節約でき，雌の間の生殖環をずらすことができ，まだ水中の慨を（他の鳥と競争なく）独占できるとい う条件である。逆に言うと，カワガラス類は一夫多妻制繁殖システムによく適応しているので，人間によ ってもたらされた彼らの生息環境における諎変化に対処することが可能である。

(吉井 正訳) 